\title{
Indian ricegrass seed damage and germination responses to mechanical treatments
}

\author{
LARRY W. GRIFFITH AND D. TERRANCE BOOTH
}

Abstract

Indian ricegrass [Oryzopsis hymenoides (Roem. and Schult.) Ricker] is a valuable forage species in the western United States; however, low fresh-seed germination has limited its use in rangeland revegetation. Seed damage and germination effeets were evaluated on 2 seedlots of 'Nezpar' Indian ricegrass exposed to 3 mechanical treatments. The air-gun scarifier and the Quaker Oats dehuller improved germination whereas the Forsberg dehuller decreased germination. Disruption of the seed cont before storage appears to be a practical method of reducing storage time required for improved germination of freshly harvested seed.

Key Words: dormancy, scarification, dehulling, Oryzopsis hymenoides, Nexpar

Indian ricegrass [Oryzopis hymenoides (Roem. and Schult.) Ricker], is a native perennial bunchgrass of western North America. It is valued as an excellent range forage, as an important wildlife food, and as an aesthetically pleasing cover on disturbed areas. Work on seed dormancy in Indian ricegrass, began in the 1930's (Huntamer 1934). Recent articles (McAdoo et al. 1983, Young et al. 1983, Zemetra et al. 1983) have reviewed past work and the current seed-dormancy hypotheses. A major cause of dormancy is thought to be the indurate lemma and palea and pericarp hull which inhibit oxygen transfer to the embryo. Dormancy gradually decreases with dry storage and germination increases with time (Plummer and Frischkecht 1952, Robertson 1976, Booth et al. 1980).

Mechanical scarification and seed dehulling by rodents have given good germination; however, acid scarification to remove or penetrate the seed coat has not been as successful and can lead to lowered viability (Stoddard and Wilkinson 1938, Zemetra and Cuany 1984, Young et al. 1985). Zemetra et al. (1983) reported mechanical scarification, using a Forsberg scarifier lined with $\mathbf{4 0}$ grade sand paper, increased germination in 2-year old seed. Treatment of l-year-old seed did not improve germination. McAdoo et al. (1983) and Young et al. (1983) have described natural establishment following dehulling and cacheing by rodents. They report germination of the seeds in the caches was enhanced by the rodent removal of the hull and that the caches were the primary means of Indian ricegrass stand renewal in the study areas.

Since rodent dehulling has increased germination, we evaluated the effect of mechanical dehulling on germination and seed damage.

\section{Methods}

Machines tested included Forsberg Model 2 Huller/Scarifier, Quaker Oats Experimental Impact Dehuller and an air-gun scarifier ${ }^{1}$. The Forsberg Model 2 is a commercial dehuller in which the seed, upon entering the hulling chamber, is rubbed against a heavy,

\footnotetext{
Authors are agricultural research technician and range scientist, USDA-ARS, High Plains Grasslands Research Station, 8408 Hildreth Rd., Cheyenne, Wyo. 82009.

The authors wish to acknowlege the contributions of the SCS-Aberdeen Plant Materials Center, Aberdeen, Ida., which provided the 'Nezpar' Indian ricegrass seed and treatment with the Quaker Oats dehuller. Seed treatment by the Forsberg dehulier was courtesy of Forsbergs Inc., Thief River Falls, Minn.

Manuscript accepted 29 February 1988.
}

'Mention of trade names is for information only and does not imply endorsement by U.S.D.A. rubber-lined steel outer-wall by an inside cylinder. This rubbing action dehulls and scarifies the seed. The Forsberg Model 2 differs from the Forsberg scarifier [used by Zemetra et al. (1983)] which employs rotating batts to propel the seed against sandpaper.

The Quaker Oats dehuller uses a rapidly rotating impeller to throw the seed against the side of a rubber-lined metal cylinder; the impact breaks the hull from the seed.

The air-gun scarifier, described by Booth and Griffith (1984), uses compressed air to shoot individual seeds into an abrasive lined cylinder. The cylinder was lined with 24 grade sanding cloth and the air gun was operated at an air pressure of $345 \mathrm{kPa}$ in this study.

'Nezpar' Indian ricegrass seed harvested in 1976 and in 1982 was treated with each machine either once or twice using approximately $1 / 2 \mathbf{~ k g}$ of seed for each experimental unit. Time to treat $1 / 2 \mathbf{~ k g}$ of seed in the Forsberg huller/scarifier, the Quaker Oats Impact Dehuller, and the air-gun scarifier was $1 / 2 \mathrm{~min}, 1 \mathrm{~min}$, and $7 \mathrm{~min}$, respectively. All seed was stored in cotton-cloth bags at $5^{\circ} \mathrm{C}$ prior to, and after, treatment. Seed was treated with the Quaker Oats dehuller in the fall of 1982. The other treatments were processed in October of 1984. Treated seed was thoroughly mixed and three 1-g subsamples randomly selected from each experimental unit for microscopic evaluation. A dissecting microscope was used to separate unhulled, dehulled, damaged seed and seed fragments from the 1-g subsamples. A seed was considered damaged if the embryo was absent or if more than $25 \%$ of the endosperm was missing. Germination tests were conducted for the Quaker Oats treatment in January 1983 and for all treatments in January 1985. Three hundred seeds of each treatment in each seedlot were incubated in dark germinators at $20^{\circ} \mathrm{C}$. Seeds were cultured on CobbJones plates (Jones and Cobb 1963) for 4 weeks and were considered germinated when the radical emerged $1 \mathrm{~mm}$. Germination was recorded each week and the germinated seeds removed from the plates.

Homogeneity of variances can not be assumed among seed treated by different machines, therefore the $95 \%$ confidence interval was used to compare germination. This provides a simple and conservative statistical test based on the normal approximation to the binomial distribution (Steel and Torrie 1980).

\section{Results and Discussion}

Treatment with the air-gun scarifier gave the best germination and the least seed damage (Table 1). Seed from the 1976 harvest that had been scarified once or twice had a mean germination of $61 \%$ and $52 \%$, respectively. Seed from the 1982 harvest that had been scarified once or twice had mean germination values of 18 and $26 \%$, respectively. The germination of all seed treated with the air gun scarifier was significantly better than that of the untreated seed.

The Forsberg dehuller caused extensive damage to both seedlots, resulting in low seed germination. The low germination was due to the removal of the embryo by the dehuller. Seed fragments from the Forsberg dehuller comprised 39 to $57 \%$ of the samples.

The germination of seed used in the 1983 test of the Quaker Oats dehuller changed significantly, from 1983 to 1985 , for all treatments except the check for the 1982 seedlot (Table 2). The 1985 germination test revealed that treated 1976 seed had reduced germination, while the germination improved for treated 1982 seed. 
Table 1. Mean germination and summary of microscopic analysis of 1 gram samples for 1976 and 1982 harvests of 'Nezpar' Indian ricegrass seed after mechanical treatments.

\begin{tabular}{|c|c|c|c|c|c|c|}
\hline \multirow[b]{2}{*}{ Treatment } & \multirow[b]{2}{*}{ Times treated } & \multicolumn{4}{|c|}{$\begin{array}{c}\text { Microscopic } \\
\text { Analysis of treated seed }\end{array}$} & \multirow[b]{2}{*}{ Fragments } \\
\hline & & Germination & Dehulled & Not dehulled & Damaged & \\
\hline & & 197 & $\ldots$ & - & $\ldots$ & $--(\mathrm{g})-$ \\
\hline Air-gun scarifier & $\begin{array}{l}1 \\
2\end{array}$ & $\begin{array}{l}61 \pm 6^{*} \\
52 \pm 6\end{array}$ & $\begin{array}{l}23.1 \\
51.5\end{array}$ & $\begin{array}{l}74.4 \\
36.9\end{array}$ & $\begin{array}{r}2.5 \\
11.6\end{array}$ & $\begin{array}{l}0.075 \\
0.181\end{array}$ \\
\hline $\begin{array}{l}\text { Quaker Oats } \\
\text { Impact Dehuller }\end{array}$ & $\begin{array}{l}1 \\
2\end{array}$ & $\begin{array}{l}48 \pm 6 \\
35 \pm 5\end{array}$ & $\begin{array}{l}48.8 \\
30.2\end{array}$ & $\begin{array}{r}19.5 \\
1.2\end{array}$ & $\begin{array}{l}31.7 \\
68.6\end{array}$ & $\begin{array}{l}0.096 \\
0.223\end{array}$ \\
\hline $\begin{array}{l}\text { Forsberg } \\
\text { Model } 2 \text { Huller/Scarifier }\end{array}$ & $\begin{array}{l}1 \\
2\end{array}$ & $\begin{array}{l}1 \pm 1 \\
0\end{array}$ & $\begin{array}{l}3.0 \\
0\end{array}$ & $\begin{array}{l}6.5 \\
1.0\end{array}$ & $\begin{array}{l}90.5 \\
99.0\end{array}$ & $\begin{array}{l}0.394 \\
0.396\end{array}$ \\
\hline Control & 0 & $24 \pm 5$ & - & - & - & - \\
\hline Air-gun scarifier & $\begin{array}{l}1 \\
2\end{array}$ & $\begin{array}{l}26 \pm 5^{*} \\
18 \pm 4\end{array}$ & $\begin{array}{l}19.6 \\
48.6\end{array}$ & $\begin{array}{l}76.4 \\
27.5\end{array}$ & $\begin{array}{r}4.0 \\
23.9\end{array}$ & $\begin{array}{l}0.089 \\
0.242\end{array}$ \\
\hline $\begin{array}{l}\text { Quaker Oats } \\
\text { Impact Dehuller }\end{array}$ & $\begin{array}{l}1 \\
2\end{array}$ & $\begin{array}{r}10 \pm 3 \\
9 \pm 3\end{array}$ & $\begin{array}{l}46.7 \\
51.2\end{array}$ & $\begin{array}{l}39.0 \\
14.4\end{array}$ & $\begin{array}{l}14.3 \\
34.4\end{array}$ & $\begin{array}{l}0.02 \\
0.079\end{array}$ \\
\hline $\begin{array}{l}\text { Forsberg } \\
\text { Model } 2 \text { Huller/Scarifier }\end{array}$ & $\begin{array}{l}1 \\
2\end{array}$ & $\begin{array}{l}1 \pm 1 \\
0\end{array}$ & $\begin{array}{l}4.9 \\
0.6\end{array}$ & $\begin{array}{l}15.1 \\
11.5\end{array}$ & $\begin{array}{l}80.0 \\
87.9\end{array}$ & $\begin{array}{l}0.525 \\
0.572\end{array}$ \\
\hline Control & 0 & $1 \pm 1$ & - & - & - & - \\
\hline
\end{tabular}

This indicates the 1985 germination test underestimates (relative to the other machines) the benefit of the Quaker Oats treatment to the 1976 seedlot and overestimates the benefit to the 1982 seedlot. For this reason Tables 1 and 2 show adjusted means for these data. The method used to adjust the means is described in footnote 3 of Table 2 .

The differential changes in germination that occurred from 1983 to 1985 between checks and treated seed may be due to greater amounts of oxygen reaching embryos of seeds with disrupted hulls. This might have caused differential 'aging' over the 2-year period, reducing the amount of germinable seed in the older seedlot while increasing germination of the younger seedlot. The differential changes in germination between treated and untreated seed indicates that maximum germination of Indian ricegrass seed can be obtained in less time if the hull of freshly harvested seed is disrupted before storage.

Most of the treated seeds which germinated were either totally dehulled and undamaged or they were seeds which retained their hulls. Scarified seed, which had the highest germination, also had the highest number of seeds not dehulled (Table 1). Microscopic inspection of these scarified seeds revealed hairline cracks in the hulls (Fig. 1), which account for the improved germination. Very few of the damaged seeds in any of the treatments germinated. It

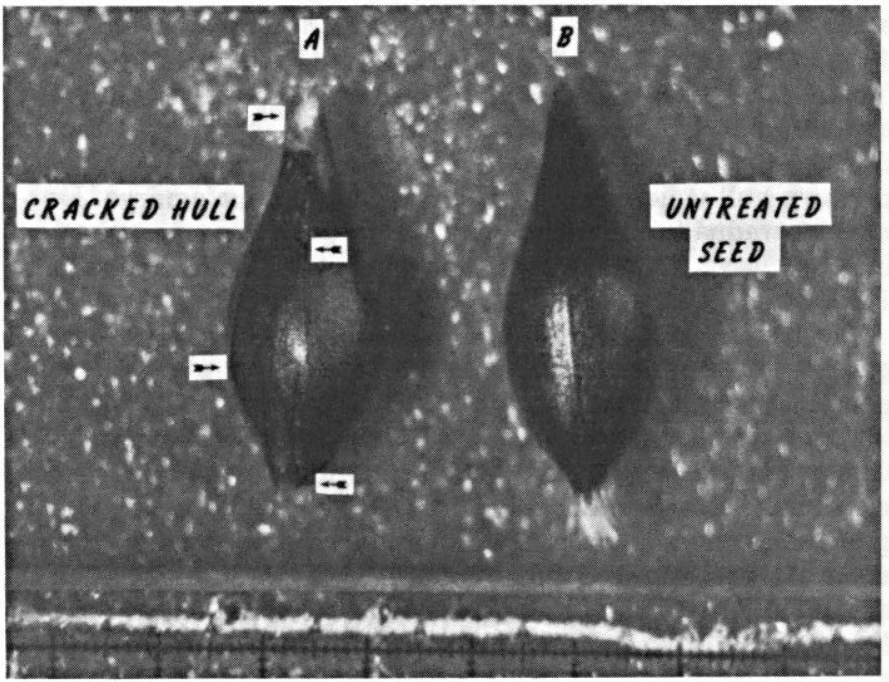

Fig. 1. A. Scarified Indian ricegrass seed exhibiting cracks and damage to hull. B. Untreated seed. $\times 14$.

Table 2. Effect of time on the percent germination of Indian ricegrass seed treated with the Quaker Oats Impact Dehuller.

\begin{tabular}{|c|c|c|c|c|c|c|}
\hline Treatment & $\begin{array}{l}\text { Jan. } 1983^{1} \\
\text { Mean germ }\end{array}$ & $\begin{array}{l}95 \% \text { Confidence } \\
\text { interval }\end{array}$ & $\begin{array}{l}\text { Jan. } 1985^{2} \\
\text { Mean germ }\end{array}$ & $\begin{array}{l}95 \% \text { Confidence } \\
\text { interval }\end{array}$ & $\begin{array}{l}\text { Germination } \\
\text { change }\end{array}$ & $\begin{array}{c}\text { Adjusted }^{3} \text { Jan. } 1985 \\
\text { Mean germ }\end{array}$ \\
\hline \multicolumn{7}{|c|}{1976 Seedlot } \\
\hline Check & 4.8 & $2-8$ & 23.7 & $19-29$ & +18.9 & \\
\hline Q. Oat $\times 1$ & 29.6 & $23-35$ & 42.0 & $36-48$ & +12.4 & 48.5 \\
\hline Q. Oat $\times 2$ & 16.0 & $11-21$ & 7.3 & 4-10 & -8.7 & 34.9 \\
\hline \multicolumn{7}{|c|}{1982 Seedlot } \\
\hline Check & 3.2 & $1-5$ & 0.7 & $0-3$ & -2.5 & \\
\hline Q. Oat $\times 1$ & 10.4 & $7-14$ & 20.7 & $16-26$ & +10.3 & 10.4 \\
\hline Q. Oat $\times 2$ & 8.8 & $5-12$ & 21.7 & $17-27$ & +12.9 & 8.8 \\
\hline
\end{tabular}

${ }^{1}$ Mean of 250 seeds.

${ }^{2}$ Mean of 300 seeds.

${ }^{3}$ Means are adjusted by adding the germination change of the check to the 1983 percent germination of the other treatments. For example $29.6+(23.7-4.8)=48.5$. The check for the 1982 seedlot did not change significantly, therefore the amount of change is taken to be zero and the 1983 germination values are used. 
was observed that the smaller seeds were less apt to be dehulled.

\section{Conclusions}

Machine scarification, because it damaged less seed yet cracked seed hulls, was better than machine dehulling for increasing germination of Indian ricegrass seed. Disruption of the hull followed by a period of dry storage appears to be a practical means of increasing the germinability of new seedlots of Indian ricegrass.

\section{Literature Cited}

Booth, D.T., C.G. Howard, and C.E. Mowry. 1980. 'Nezpar' Indian ricegrass: description, justification for release, and recommendations for use. Rangelands. 2:53-54.

Booth, D.T., and L.W. Grifnth. 1984. Evaluation of air thresing for small lots of winterfat fruits. J. Range Manage. 37:286-287.

Huntamer, M.Z. 1934. Dormancy and delayed germination of Oryzopsis hymenoides. M.S. Thesis, State College of Washington, Pullman.

Jones, L.G., and R.D. Cobb. 1963. A technique for increasing the speed of laboratory germination testing. proc. Assoc. Offic. Seed Analysts $53: 144-160$.
McAdoo, J.K., C.C. Evans, B.A. Roundy, J.A. Young, and R.A. Evans. 1983. Influence of heteromyid rodents on Oryzopsis hymenoides germination. J. Range Manage. 36:61-64.

Plummer, A.P., and N.C. Friachknecht. 1952. Increasing stands of Indian ricegrass. Agron. J. 44:285-289.

Robertson, J.H. 1976. The autecology of Oryzopsis hymenoides. Mentzelia. 2:18-21 and 25-27.

Steel, R.G.D., and J.H. Torrie. 1980. Principles and procedures of statistics. McGraw-Hill New York. p. 479.

Stoddard, L.A., and K.J. Willinson. 1938. Inducing germination in Oryzopsis hymenoides for range reseeding. J. Amer. Soc. Agron. 30:763-768.

Young, J.A., R.A. Evans, and B.A. Roundy. 1983. Quantity and germination of Oryzopsis hymenoides seed in Lahontan sands. J. Range Manage. 36:82-86.

Youne, J.A., R.A. Evans, and D.A. Eadi. 1985. Enhancing germination of Indian ricegrass seeds with sulfuric acid. Agron. J. 77:203-206.

Zemetra, R.S., C. Havstad, and R.L. Cuany. 1983. Reducing seed dormancy in Indian ricegrass ,Oryzopsis hymenoides, J. Range Manage. 36:239-241.

Zemetra, R.S., and R.L. Cuany. 1984. Variation in lemma thickness in Indian ricegrass: Implications for dormancy, scarification, and breeding. Crop Sci. 24:1082-1084. 